Volume 2 Nomor 1 Edisi Juni 2013

ISSN 2354-7200
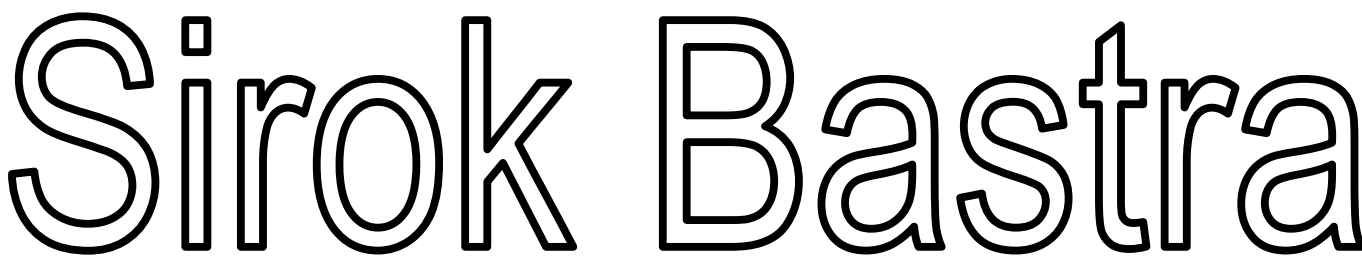

JURNAL ILMIAH KEBAHASAAN DAN KESASTRAAN

\begin{tabular}{|c|c|l|c|c|c|}
\hline $\begin{array}{c}\text { Sirok Bastra } \\
\text { Jurnal Kebahasaan dan } \\
\text { Kesastraan }\end{array}$ & Volume 2 & Nomor 1 & $\begin{array}{c}\text { Hlm. } \\
1-120\end{array}$ & $\begin{array}{c}\text { Pangkalpinang, } \\
\text { Juni 2013 }\end{array}$ & $\begin{array}{c}\text { ISSN } \\
2354-7200\end{array}$ \\
\hline
\end{tabular}

KANTOR BAHASA PROUINSI BANGKA BELITUNG 


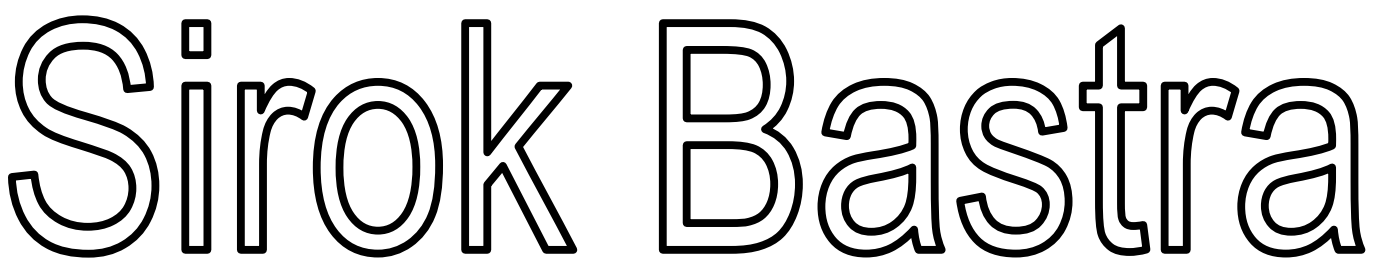

\section{JURNAL ILMIAH KEBAHASAAN DAN KESASTRAAN}

Jurnal ini merupakan wadah informasi mengenai kebahasan, kesastraan, dan pengajarannya yang memuat hasil penelitian, studi kepustakaan, dan tulisan ilmiah bidang kebahasan dan kesastraan serta pengajarannya. Sirok Bastra terbit dua kali setahun, yakni Juni dan Desember, serta terbit sejak Juni 2013.

\section{Penanggung Jawab}

Kepala Kantor Bahasa Provinsi Bangka Belitung Drs. Umar Solikhan, M.Hum.

\section{Mitra Bestari}

Prof. Dr. Agus Nuryatin, M.Hum. (Bidang Sastra dan Pengajarannya)

Prof. Amrin Saragih, Ph.D., M.A. (Bidang Bahasa dan Pengajarannya)

Dr. Felicia Nuradi Utorodewo, M.Hum. (Bidang Bahasa dan Pengajarannya)

Dr. Pujiharto, M.Hum. (Bidang Sastra dan Pengajarannya)

\section{Pemimpin Redaksi}

Rahmat Muhidin, S.S.

\section{Penyunting}

Prima Hariyanto, S.Hum.

\section{Perancang Sampul}

Feri Pristiawan, S.S.

\section{Kesekretariatan}

Khaliffitriansyah, S.Pd.

Dea Letriana Cesaria, S.Hum.

Lia Aprilina, S.Pd.

Andrian Priyatno, A.Md.

Elzam

\section{Alamat Redaksi dan Penerbit}

Kantor Bahasa Provinsi Bangka Belitung

Ruko Permata 7, Jalan Solihin G.P. Km 4, Kota Pangkalpinang, Prov. Kepulauan Bangka Belitung

Telp./Faks.: 0717-438455, Pos-el: sirokbastra@gmail.com

Pemuatan suatu tulisan dalam jurnal ini tidak berarti redaksi menyetujui isi tulisan tersebut. Isi tulisan menjadi tanggung jawab penulis. Tulisan telah ditinjau dan diulas oleh mitra bestari. Setiap karangan dalam jurnal ini dapat diperbanyak setelah mendapat izin tertulis dari penulis, redaksi, dan penerbit. 


\section{PENGANTAR}

Puji syukur ke hadirat Pemilik dan Pencipta semesta ini yang memiliki kuasa atas diri-Nya sendiri. Dialah Tuhan Yang Maha Esa yang telah memberikan rahmat dan hidayah-Nya sehingga Volume 2 Nomor 1 Jurnal Sirok Bastra Tahun 2014 dapat terbit tepat pada waktunya.

Pada edisi ini, dimuat sepuluh tulisan, yakni enam tulisan kesastraan dan empat tulisan kebahasaan. Dalam kajiannya, Anita Rima Dewi melihat kedudukan perempuan Jawa dalam keluarga — tergambar dalam novel Hati Sinden karya Dwi Rahyuningsih — dilihat dari perspektif gender. Berdasarkan penelitian, ditemukan bahwa diskriminasi gender seperti marginalisasi, stereotipe, dan subordinasi melahirkan berbagai kekerasan, yakni ekonomi, fisik, psikis, dan seksual.

Dalam kajiannya, Sarman membahas mitos buluh perindu dalam cerita rakyat Bangka. Mitos Bukit Tambun Tulang memuat struktur geografis yang menunjukkan adanya pola perjalanan hidup tokoh dalam mempertahankan hidup; struktur tekno-ekonomi yang menunjukkan adanya sistem mata pencaharian orang Bangka, antara lain berburu dan berkebun; struktur sosiologis yang menunjukan adanya hubungan sosial antara sesama manusia; dan struktur kosmologis yang menunjukkan adanya keterkaitan antara dunia nyata dan dunia gaib.

Dalam penelitiannya, Iis Afriatiningsih membahas sosok perempuan dalam karya sastra Indonesia yang diwakili oleh Nyai Ontosoroh, Pariyem, Clara yang menghadapi banyak tantangan dalam hidupnya. Hasil analisis menunjukkan bahwa sosok perempuan memiliki sikap, seperti memperjuangkan hidupnya (tergambar dalam tokoh Nyai Ontosoroh), pasrah dengan nasibnya (tergambar dalam tokoh Pariyem), dan nasibnya ada di tangan rakyat kecil (tergambar dalam tokoh Clara). Perjuangan perempuan tersebut berkaitan dengan kritik formalisme, strukturalisme, posstrukturalisme, dan posmoderenisme.

Dalam kajiannya, Asep Supriadi mengaplikasikan teori takmilah yang digagas oleh seorang pakar sastra Melayu bernama Shafie Abu Bakar pada puisi "Idul Fitri" karya Sutardji Calzoum Bachri. Hasil kajian menunjukkan bahwa puisi tersebut menggambarkan nilai-nilai keislaman dengan dimensi sufistik. Puisi itu menggambarkan perenungan eksistensi diri pada Tuhan.

Dalam kajiannya, Ch. Haris Maulana membahas tokoh dan penokohan serta nilai moral dan kekhasan yang ada dalam serial Harry Potter, khususnya seri pertama, Harry Potter dan Batu Bertuah. Nilai moral dan kekhasan yang tersirat dalam serial ini adalah sihir dapat dipelajari dan bukan faktor keturunan, kesetiakawanan, kedisipilinan, kepedulian, dan keingintahuan.

Dalam penelitiannya, Dwi Oktarina menggali aspek hibriditas dan ambivalensi yang terjadi pada tokoh Mata Hari dalam novel Namaku Mata Hari karya Remy Silado. Mata Hari, seorang agen spionase keturunan Belanda-Jawa bekerja pada banyak negara pada saat perang dunia berkecamuk. Selain itu, permainan politik tubuh Mata Hari juga menjadi sebuah hal yang menarik untuk diteliti lebih jauh. Berdasarkan penelitian, didapatkan hasil bahwa ruang-ruang pertemuan antara dua kebudayaan sama sekali tidak bisa dielakkan. Mata Hari sebagai Indo berdarah campuran Belanda-Indonesia tidak dapat melepaskan dirinya dari dua kebudayaan yang melingkupinya, Belanda maupun Indonesia.

Dalam kajiannya, Maria Christa Istiana Kamagi membahas struktur kalimat dan keterbacaan pada buku teks pelajaran bahasa Indonesia. Berdasarkan penelitian, ditemukan kalimat tunggal perluasan subjek, predikat, objek, dan pelengkap, kalimat tunggal perluasan keterangan, kalimat majemuk setara, kalimat majemuk bertingkat, kalimat majemuk bersusun, dan kalimat taklengkap. Selain menjelaskan struktur kalimat yang ada, penelitian ini juga mencoba menganalisis keterbacaan dilihat dari jumlah kata yang digunakan dalam kalimat tersebut. Hasil yang didapat adalah terdapat beberapa kalimat yang masih masuk kategori kalimat sulit dan sangat sulit dipahami.

Dalam kajiannya, Achril Zalmansyah membahas hasil Uji Kemahiran Berbahasa Indonesia (UKBI) guru dan siswa SMP di Kabupaten Lampung Utara. Data yang diperoleh menunjukkan bahwa sebagian besar peserta memperoleh nilai antara 300-400 yang berarti cukup baik. Dengan demikian, dapat dikatakan bahwa UKBI 
merupakan alat uji yang dapat digunakan untuk mengukur penguasaan bahasa Indonesia seorang guru serta penggunaan bahasa Indonesia yang baik dan benar oleh siswa.

Dalam kajiannya, Prima Hariyanto membahas kata berinfiks -er- dalam bahasa Indonesia. Korpus data penelitian ini adalah Kamus Besar Bahasa Indonesia Edisi Ketiga. Berdasarkan penelitian yang dilakukan, ditemukan 62 kata berinfiks -er- yang terdiri dari 14 jenis kelompok makna. Selain memaparkan kata berinfiks yang ada, penelitian ini juga mencoba memaparkan metode pendefinisian lema kata berinfiks yang -er-bermakna 'sama dengan bentuk dasarnya' dalam Kamus Besar Bahasa Indonesia.

Dalam penelitiannya, Hotnida Novita Sary mengkaji perbedaan bentuk verba yang terdapat dalam bahasa Melayu Tinggi dan bahasa Melayu Rendah yang terdapat dalam Injil Matius terjemahan Klinkert. Peneliti mengunduh data dari laman sabda.org. Kedua versi Injil Matius ini kemudian dibandingkan dan dicatat satu ayat dengan ayat yang sama. Hasil pencatatan inilah yang dianalisis. Hasil yang didapatkan dari penelitian ini adalah ragam bahasa Melayu Tinggi cenderung menggunakan bentuk berimbuhan, sedangkan bahasa Melayu Rendah cenderung menggunakan bentuk dasar.

Kami mengucapkan terima kasih kepada para penulis yang telah bersedia menerbitkan karya mereka pada edisi ini. Para penulis merupakan peneliti, pakar, dosen, siswa, dan mahasiswa dari berbagai sekolah, perguruan tinggi, dan instansi. Terima kasih juga kami sampaikan kepada para mitra bestari kami yang telah memberi ulasan terhadap tulisan-tulisan yang masuk ke redaksi.

Demi memenuhi keberagaman isi dan penulis, Sirok Bastra membuka kesempatan bagi para peneliti dan penulis menyampaikan hasil penelitian dan pemikiran mutakhir dalam bidang kebahasaan, kesastraan, dan pengajarannya.

Pangkalpinang, Juni 2014

Tim Redaksi 


\section{UCAPAN TERIMA KASIH UNTUK MITRA BESTARI}

Redaksi Sirok Bastra mengucapkan terima kasih kepada para mitra bestari yang telah meninjau, menimbang, dan mengulas makalah-makalah yang diterbitkan dalam Sirok Bastra Volume 2 Nomor 1, edisi Juni 2014, yakni

Prof. Dr. Agus Nuryatin, M.Hum.

Bidang Sastra dan Pengajarannya

Universitas Negeri Semarang

Semarang, Jawa Tengah

Prof. Amrin Saragih, Ph.D., M.A.

Bidang Bahasa dan Pengajarannya

Universitas Negeri Medan

Medan, Sumatra Utara

Dr. Felicia Nuradi Utorodewo, M.Hum.

Bidang Bahasa dan Pengajarannya

Universitas Indonesia

Depok, Jawa Barat

\section{Dr. Pujiharto, M.Hum.}

Bidang Sastra dan Pengajarannya

Universitas Gadjah Mada

Yogyakarta, Daerah Istimewa Yogyakarta 


\section{DAFTAR ISI}

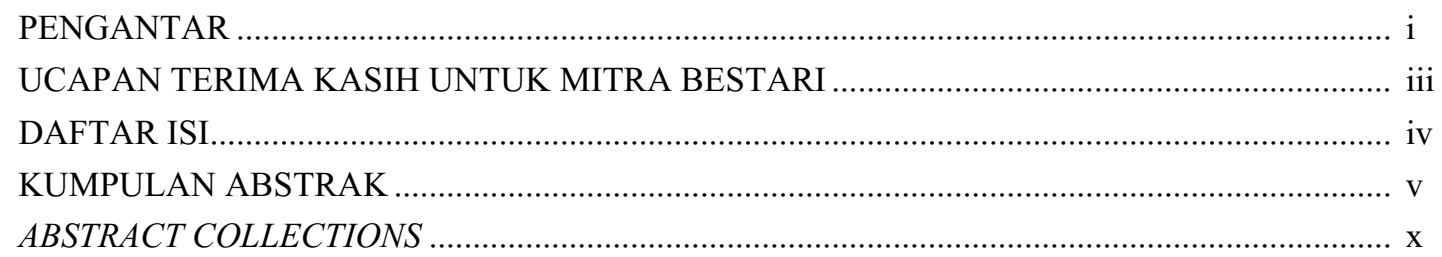

KEDUDUKAN PEREMPUAN JAWA DALAM NOVEL HATI SINDEN KARYA DWI RAHYUNINGSIH DILIHAT DARI PERSPEKTIF GENDER

(The Position of Javanese Women Based on Gender Perspective in Hati Sinden, a Novel by Dwi Rahyuningsih)

Anita Rima Dewi $1-15$

MITOS DALAM CERITA “BUKIT TAMBUN TULANG”

(Myth in "Bukit Tambun Tulang" Story)

Sarman. $17-24$

SOSOK PEREMPUAN DARI ZAMAN KE ZAMAN DALAM KARYA SASTRA INDONESIA: STUDI KASUS TOKOH NYAI ONTOSOROH, PARIYEM, DAN CLARA (Figure of Women from Time to Time in Indonesian Literary Works: A Case Study of Nyai Ontosoroh, Pariyem, and Clara)

Iis Afriatiningsih $25-33$

MEMAHAMI PUISI "IDUL FITRI" DENGAN TEORI TAKMILAH

(Understanding the Poetry "Idul Fitri” by Using Theory of Takmilah)

Asep Supriadi $35-44$

NILAI DAN KEKHASAN SERIAL HARRY POTTER (KAJIAN HARRY POTTER 1: HARRY POTTER DAN BATU BERTUAH)

(Value and Uniqueness of Harry Potter Series [A Study of Harry Potter 1: Harry Potter and The Sorcerers Stone])

Ch. Haris Maulana $45-52$

HIBRIDITAS DAN POLITIK TUBUH DALAM NOVEL NAMAKU MATA HARI KARYA REMY SILADO: SEBUAH TINJAUAN POSKOLONIAL

(Hybridity and Body Politic in Namaku Mata Hari, A Novel Written by Remy Silado: A Postcolonial Study)

Dwi Oktarina $53-61$

STRUKTUR DAN KETERBACAAN KALIMAT PADA BUKU TEKS PELAJARAN BAHASA INDONESIA

(Sentence Structure and Readability in Indonesian Textbook)

Maria Christa Istiana Kamagi. $63-78$ 
UJI KEMAHIRAN BERBAHASA INDONESIA (UKBI) BAGI GURU DAN SISWA SEKOLAH MENENGAH PERTAMA SE-LAMPUNG UTARA

(Indonesian Proficiency Test [UKBI] for Teacher and Junior High School Students All Lampung Utara)

Achril Zalmansyah

KATA BERINFIKS -ER- DALAM BAHASA INDONESIA

(-er- Infixes Words in Indonesian)

Prima Hariyanto

$89-103$

PERBEDAAN BENTUK VERBA PADA BAHASA MELAYU TINGGI DAN BAHASA

MELAYU RENDAH: STUDI KASUS INJIL MATIUS TERJEMAHAN KLINKERT

(Verb Form of Differences in Language Malay Malay Language High and Low: Case Study of The Gospel of Matthew Klinkert Translations)

Hotnida Novita Sary .... $105-120$ 
Maria Christa I.K.: Struktur dan Keterbacaan Kalimat pada Buku Teks Pelajaran ...

\title{
STRUKTUR DAN KETERBACAAN KALIMAT PADA BUKU TEKS PELAJARAN BAHASA INDONESIA
}

\author{
Sentence Structure and Readability in Indonesian Textbook \\ Maria Christa Istiana Kamagi \\ Fakultas Ilmu Pengetahuan Budaya, Universitas Indonesia \\ Kampus Baru UI Depok, Jawa Barat \\ Pos-el: mariachrista.kamagi@yahoo.com
}

(diterima 11 Maret 2014, disetujui 8 April 2014, revisi terakhir 3 Juni 2014)

\begin{abstract}
Abstrak
Kajian ini membahas struktur kalimat dan keterbacaan pada buku teks pelajaran bahasa Indonesia. Penelitian ini menggunakan metode kualitatif, sedangkan teknik pengumpulan data yang digunakan adalah analisis kepustakaan.Berdasarkan penelitian yang dilakukan, ditemukan kalimat tunggal perluasan subjek, predikat, objek, dan pelengkap, kalimat tunggal perluasan keterangan, kalimat majemuk setara, kalimat majemuk bertingkat, kalimat majemuk bersusun, dan kalimat taklengkap. Selain menjelaskan struktur kalimat yang ada, penelitian ini juga mencoba menganalisis keterbacaan dilihat dari jumlah kata yang digunakan dalam kalimat tersebut. Hasil yang didapat adalah terdapat beberapa kalimat yang masih masuk kategori kalimat sulit dan sangat sulit dipahami.
\end{abstract}

Kata kunci: struktur kalimat, keterbacaan, buku teks, pelajaran bahasa Indonesia

\begin{abstract}
This study discussed about the structure of sentence and readability of Indonesia's textbooks. This study used qualitative methods, while the data collecting used bibliography analysis. Based on research, it found expansion of subject, predicate,object, and complement on single sentence, the adverb expansion on single sentence, the equivalent compound sentence, the hig-rise compound sentence, the compiling compound sentence, and the incomplete sentence. Beside that, this study also analyzed the readability which was seen from the number of words that use in the sentence. As a result, there are some sentences that can be categorized into difficult sentence and thorny sentence to be comprehended.
\end{abstract}

Key words: structure of sentence, readability, textbook, Indonesian lesson

\section{PENDAHULUAN}

\subsection{Latar Belakang}

Bahasa Indonesia mulai diajarkan pada siswa sejak kelas 1 sekolah dasar. Hal ini dilakukan agar dari usia dini siswa dapat mengenal dengan baik bahasa Indonesia. Selain itu, hal tersebut dilakukan agar pada tingkat pendidikan menengah dan tinggi, siswa tidak lagi merasa kesulitan beradaptasi dengan pelajaran bahasa Indonesia. Pengajaran yang telah dimulai sejak usia dini tersebut ternyata tidak begitu signifikan dalam membuat para siswa mahir menggunakan keterampilan bahasa Indonesia. Hal ini dapat dilihat dari semakin menurunnya nilai rata-rata ujian nasional sekolah menengah atas selama 15 tahun terakhir ${ }^{1}$. Pada jenjang pendidikan menengah—dalam hal ini SMA—siswa seharusnya mendapat nilai yang baik karena mata pelajaran bahasa Indonesia telah sejak lama mereka dapatkan. Dengan demikian, berdasarkan hal ini, penulis menarik kesimpulan sementara bahwa pengajaran bahasa Indonesia di sekolah masih belum dapat dikatakan berhasil.

Salah satu penyebab kurang berhasilnya pengajaran bahasa Indonesia di sekolah adalah buku pelajaran yang digunakan kurang disukai siswa. Hal ini terjadi karena beberapa faktor, misalnya, bahasa di dalam buku pelajaran tersebut yang tertuang dalam wacana atau teks sulit dipahami sehingga siswa cenderung merasa bosan untuk membaca apalagi mempelajarinya. Selain itu, materi atau konten pelajaran bahasa Indonesia yang berkesan hanya mengulang materi di tingkat pendidikan sebelumnya 
Maria Christa I.K.: Struktur dan Keterbacaan Kalimat pada Buku Teks Pelajaran ...

juga membuat siswa merasa jenuh menggunakan buku tersebut.

Menurut Tata Bahasa Baku Bahasa Indonesia, wacana adalah rentetan kalimat yang berkaitan sehingga terbentuklah makna yang serasi di antara kalimat-kalimat itu. Berdasarkan penjelasan tersebut, dapat dikatakan bahwa kalimat merupakan salah satu unsur pembangun sebuah wacana (bacaan). Hal ini berlaku pula pada buku teks pelajaran bahasa Indonesia. Kalimat-kalimat dalam buku teks pelajaran bahasa Indonesia disusun menjadi sebuah wacana (bacaan) sehingga dapat dikatakan kalimat merupakan penentu atau indikator bacaan buku pelajaran tersebut dipahami atau tidak. Dengan kata lain, analisis terhadap kalimat khususnya struktur kalimat dapat digunakan untuk melihat keterbacaan sebuah. Yang dimaksud keterbacaan di sini adalah kemampuan seseorang-dalam hal ini siswa SMA-memahami suatu bacaan atau teks. Menurut Kridalaksana, keterbacaan adalah taraf dapat-tidaknya suatu karya tulis dibaca dan dipahami oleh orang yang mempunyai kemampuan membaca berbedabeda(2001: 109). Keterbacaan berkaitan pula dengan keberhasilan pembaca dalam memahami materi yang dibacanya pada kecepatan membaca yang optimal (Dale \& Chall dalam Gilliland, 1972).

Kalimat yang disajikan dalam teks dan bacaan turut pula menjadi sebagian besar materi ujian nasional (UN) mata pelajaran bahasa Indonesia SMA. Dalam ujian nasional, baik bacaan umum maupun bacaan sastra, disajikan dalam jumlah yang cukup banyak $^{2}$. Oleh karena itu, penelitian mengenai kalimat dalam buku teks pelajaran bahasa Indonesia sebagai salah satu bahan belajar siswa perlu dilakukan.

\subsection{Masalah}

Buku pelajaran sebagai sarana pendukung dalam proses pembelajaran bahasa Indonesia harus memadai kebutuhan siswa. Keberadaan kalimat sebagai salah satu faktor penentu keterbacaan dalam buku teks pelajaran bahasa Indonesia tersebut perlu dianalisis lebih lanjut agar dapat diketahui kalimat seperti apa yang mudah dipahami siswa. Namun, sejauh ini belum ada penelitian memadai mengenai kalimat dalam buku teks pelajaran bahasa Indonesia. Berdasarkan hal tersebut, permasalahan yang akan dibahas pada penelitian ini adalah sebagai berikut.
1. Bagaimana struktur kalimat buku teks pelajaran bahasa Indonesia terbitan tahun 1988, buku terbitan 2001, dan buku terbitan 2008 ?

2. Bagaimana keterbacaan kalimat buku teks pelajaran bahasa Indonesia terbitan tahun 1988, buku terbitan 2001, dan buku terbitan 2008 dilihat dari jumlah katanya?

\subsection{Tujuan}

Berdasarkan permasalahan yang ditemukan, tujuan penelitian ini adalah sebagai berikut.

1. Menjelaskan struktur kalimat dalam buku teks pelajaran bahasa Indonesia terbitan tahun 1988, buku terbitan tahun 2001, dan buku terbitan tahun 2008.

2. Menjelaskan keterbacaan buku terbitan tahun 1988, buku terbitan 2001, dan buku terbitan tahun 2008 ditinjau dari jumlah kata yang digunakan.

\subsection{Manfaat}

Penelitian ini memiliki manfaat praktis dan teoretis. Manfaat teoretis dari penelitian ini antara lain menambah dan melengkapi khazanah penelitian dalam cabang ilmu sintaksis, khususnya kalimat. Di samping itu, penelitian ini juga bermanfaat menambah perbendaharaan informasi dan referensi bagi perkembangan ilmu linguistik di Indonesia.Penelitian ini juga dapat memberikan kontribusi dalam rangka pengembangan dan pembinaan bahasa Indonesia. Selanjutnya, manfaat praktis dari penelitian ini adalah mengetahui perkembangan bahasa Indonesia, khususnya bahasa Indonesia yang diajarkan di lembaga pendidikan (sekolah). Bagi praktisi pendidikan seperti guru dan pengajar, hasil penelitian ini dapat digunakan sebagai acuan atau referensi untuk menghasilkan buku ajar yang lebih baik lagi. Bagi masyarakat umum, hasil penelitian ini dapat pula memberikan pengetahuan tentang buku teks pelajaran bahasa Indonesia yang baik untuk digunakan.

\subsection{Metode Penelitian dan Data}

Metode yang digunakan dalam penelitian ini adalah metode kualitatif. Metode ini lebih mementingkan proses daripada hasil dan analisis datanya lebih banyak secara naratif. Metode penelitian kualitatif digunakan untuk mendapatkan data yang mendalam, suatu data yang mengandung makna. Makna adalah data yang sebenarnya, data 
Maria Christa I.K.: Struktur dan Keterbacaan Kalimat pada Buku Teks Pelajaran ...

yang pasti yang merupakan suatu nilai di balik data yang tampak. Oleh karena itu, penelitian kualitatif tidak menekankan generalisasi tetapi lebih menekankan pada makna (Sugiyono, 2008: 2).

Teknik pengumpulan data yang digunakan dalam penelitian ini adalah analisis kepustakaan. Teknik kepustakaan digunakan untuk mengumpulkan bukubuku teks pelajaran bahasa Indonesia terbitan lama dan terbitan baru. Penulis mengambil korpus data dari buku teks pelajaran bahasa Indonesia kelas 3 SMA terbitan tahun 1988 yang menggunakan kurikulum 1984, terbitan tahun 2001 yang menggunakan suplemen 1999 (pembelajaran mengarah pada kurikulum Kompetensi Dasar), dan terbitan tahun 2008. Dari pengambilan korpus data tersebut, diharapkan data yang digunakan dalam penelitian ini mewakili perkembangan buku teks pelajaran bahasa Indonesia selama kurun waktu tertentu. Hal tersebut didasari dengan adanya asumsi bahwa pada tingkatan yang merupakan tingkatan tertinggi di sekolah ini, para siswa telah mencapai waktu maksimal dalam pembelajaran bahasa Indonesia pada tingkat pendidikan menengah.
Tahap-tahap pengumpulan data meliputi pencarian data dan klasifikasi data. Pencarian data dilakukan di Pusat Perbukuan dan Kurikulum Departemen Pendidikan dan Kebudayaan. Tahap selanjutnya adalah tahap klasifikasi data. Setelah mendapatkan pelajaran yang dimaksud, penulis memilih satu bacaan pada pelajaran yang memiliki bacaan lebih dari satu. Kriteria pemilihannya adalah sebagai berikut. Bacaan yang akan menjadi data merupakan banyak dengan jumlah kalimat paling sedikit dari bacaan yang lainnya serta bacaan tersebut tidak memuat grafik, tabel, diagram, hasil wawancara, percakapan atau dialog. Kemudian, dari jumlah bab atau pelajaran yang telah didapat penulis hanya mengambil setengah dari jumlah tersebut. Misalnya, dari buku terbitan tahun 2008 terdapat 11 pelajaran yang memiliki bacaan sesuai dengan kriteria, penulis hanya mengambil 5 pelajaran untuk dijadikan sebagai data. Berikut adalah jumlah kalimat yang dianalisis. Kalimat yang dianalisis lebih lanjut adalah kalimat deklaratif sehingga kalimat interogatif, imperatif, dan eksklamatif tidak diikutsertakan.

Jumlah Kalimat pada Buku Terbitan 1988, 2001, dan 2008

\begin{tabular}{|c|c|c|c|}
\hline No. & & Judul Bacaan & $\begin{array}{l}\text { Jumlah } \\
\text { Kalimat }\end{array}$ \\
\hline \multirow{4}{*}{1.} & \multirow{4}{*}{$\begin{array}{c}\text { Buku } \\
\text { terbitan } \\
1988\end{array}$} & Pelajaran 5 Enam Bulan Setelah Devaluasi 12 September 1986 & 34 \\
\hline & & Pelajaran 6 Industri Kecil Mempunyai Nilai Strategis & 23 \\
\hline & & Pelajaran 7 Hidup Sehat Dimulai dari Rumah & 33 \\
\hline & & Pelajaran 8 Dengan Bambu Mereka Melaut & 29 \\
\hline \multirow{7}{*}{2.} & \multirow{7}{*}{$\begin{array}{c}\text { Buku } \\
\text { terbitan } \\
2001\end{array}$} & Pelajaran 1 Seni Patung yang Tertidur & 28 \\
\hline & & Pelajaran 2 Buku Dapat Membentuk Budaya Modern & 12 \\
\hline & & Pelajaran 3 Tekan Angka Kematian Ibu Hamil & 19 \\
\hline & & Pelajaran 5 Pagar Pembatas Jalan Matraman Raya Dijebol & 23 \\
\hline & & Pelajaran 11 Jika Saya Menjadi Pahlawan Masa Kini & 17 \\
\hline & & Pelajaran 12 Mobil Listrik Ternyata Mahal dan Tidak Praktis & 29 \\
\hline & & Pelajaran 17 Disiplin & 32 \\
\hline \multirow{6}{*}{3.} & \multirow{5}{*}{$\begin{array}{c}\text { Buku } \\
\text { terbitan } \\
2008\end{array}$} & Pelajaran 1 Langkah Pasti Memulai Bisnis dengan Konsep & 29 \\
\hline & & Pelajaran 6 Kebijakan Hanya untuk Elit Politik & 29 \\
\hline & & Pelajaran 7 Monster Bergiat di Pintu Jakarta & 32 \\
\hline & & Pelajaran 8 Fenomena Nasi Aking dalam Potret Kemiskinan & 35 \\
\hline & & Pelajaran 10 Anthurium Nan Menawan & 35 \\
\hline & & TOTAL & 439 \\
\hline
\end{tabular}


Maria Christa I.K.: Struktur dan Keterbacaan Kalimat pada Buku Teks Pelajaran ...

\section{KERANGKA TEORI}

\subsection{Kalimat}

Kalimat merupakan salah satu faktor penentu atau indikator sebuah bacaan dapat dipahami atau tidak. Menurut Harimurti Kridalaksana (1999:184), kalimat adalah satuan bahasa yang relatif berdiri sendiri, mempunyai ciri utama berupa intonasi final dan secara aktual maupun potensial terdiri dari klausa. J.D. Parera (1993:4) mengemukakan bahwa sebuah kalimat mempunyai ciri kesenyapan final yang menunjukkan bentuk itu berakhir.Dari hal tersebut, dapat disimpulkan bahwa penentuan sebuah bentuk bahasa sebagai kalimat didasari oleh dua aspek penting, yaitu bentuk bahasa tersebut dapat berdiri sendiri dan bentuk bahasa tersebut memiliki intonasi final.Pembatasan sebuah kalimat dalam Tata Bahasa Baku Bahasa Indonesia sedikit berbeda dengan definisi Harimurti dan Parera. Menurut TBBI (2003:311), kalimat adalah satuan bahasa terkecil dalam wujud lisan atau tulisan, yang mengungkapkan pikiran yang utuh.

Menurut Kridalaksana, jenis-jenis kalimat dapat ditandai oleh jumlah klausa di dalamnya, struktur klausa, kategori predikatnya, pola intonasi, dan amanat wacana. Berdasarkan jumlah klausanya, kalimat dapat dibagi menjadi kalimat tunggal, kalimat bersusun, kalimat majemuk yang dibagi lagi menjadi kalimat majemuk setara dan kalimat majemuk bertingkat, kalimat bertopang, dan kombinasi keempat jenis kalimat itu.Berdasarkan struktur klausanya, kalimat dapat dibagi menjadi kalimat lengkap dan taklengkap. Berdasarkan, kategori predikatnya, kaliamt dapat dibagi menjadi kalimat verbal dan kalimat nonverbal, sedangkan berdasarkan pola intonasinya, kalimat dapat dibagi menjadi kalimat deklaratif, kalimat interogatif, kalimat imperatif, kalimat aditif, kalimat responsif, dan kalimat ekslamatif.

Adapun TBBI mengelompokkan kalimat yang ditinjau berdasarkan jumlah klausanya (yang terdiri atas kalimat tunggal dan kalimat majemuk), bentuk atau kategori sintaksisnya (yang terdiri atas kalimat deklaratif, kalimat imperatif, kalimat interogatif, dan kalimat ekslamatif), kelengkapan unsurnya, dan susunan subjek dan predikatnya (kalimat inversi dan kalimat non-inversi).
Dari paparan di atas, dapat dilihat bahwa pengklasifikasian yang ada di setiap teori memuat dua hal penting, yaitu pengklasifikasian berdasarkan jumlah klausa dan pengklasifikasian berdasarkan kelengkapan unsur atau struktur klausa. Bagi peneliti, kedua pengklasifikasian tersebut merupakan dasar atau hal terpenting dalam menggolongkan sebuah kalimat. Oleh karena itu, pada penelitian ini hanya dibahas kalimat berdasarkan jumlah klausa dan struktur klausa.Yang termasuk ke dalamnya adalah kalimat tunggal dan kalimat majemuk dan kalimat lengkap dan taklengkap.

\subsection{Keterbacaan}

Keterbacaan (readability) adalah seluruh unsur yang ada dalam teks (termasuk di dalamnya interaksi antarteks) yang berpengaruh terhadap keberhasilan pembaca dalam memahami materi yang dibacanya pada kecepatan membaca yang optimal (Gilliland, 1972:12). Hampir serupa dengan hal tersebut, Harjasujana dan Mulyati menyampaikan bahwa keterbacaan berkaitan dengan perihal terbaca-tidaknya wacana oleh pembacanya (1996:63). Pandangan senada dapat pula dilihat dalam konsep yang dipaparkan oleh Depdikbud (2005:11-12) yang memaknai keterbacaan sebagai perihal kemudahan baca bagi siswa. Dari definisi-defisini tersebut dapat disimpulkan bahwa keterbacaan adalah perihal terbaca atau tidaknya suatu bacaan yang unsur terpentingnya terdapat pada bacaan itu sendiri.

Penelitian ini berfokus pada penelitian bangun atau struktur kalimat. Salah satu cara untuk mengukur keterbacaan kalimat adalah dengan menghitung jumlah kata yang digunakan dalam kalimat tersebut. Felicia Nuradi Utorodewo dalam makalahnya pada Seminar Bahasa dan Sastra Indonesia yang berjudul "Tinjauan Buku Teks Pelajaran Bahasa Indonesia" mengutip penelitian keterbacaan kalimat dalam surat kabar bagi orang dewasa sebagai pegangan. Kutipan keterbacaan tersebut adalah (1) kalimat yang terdiri atas 8 kata atau kurang merupakan kategori kalimat yang sangat mudah dipahami; (2) kalimat yang terdiri atas 11 kata merupakan kategori kalimat yang mudah dipahami; (3) kalimat yang terdiri atas 14 kata merupakan kategori kalimat yang agak mudah dipahami; (4) kalimat yang terdiri atas 17 kata merupakan kategori kalimat yang standar; (5) kalimat 
Maria Christa I.K.: Struktur dan Keterbacaan Kalimat pada Buku Teks Pelajaran ...

yang terdiri atas 21 kata merupakan kategori kalimat yang agak sulit dipahami; (6) kalimat yang terdiri atas 25 kata merupakan kategori kalimat yang sulit dipahami; dan (7) kalimat yang terdiri atas 29 kata atau lebih merupakan kategori kalimat yang sangat sulit dipahami.

\section{HASIL DAN PEMBAHASAN}

\subsection{Struktur Kalimat Tunggal dengan Perluasan S, P, O, dan Pelengkap}

Berdasarkan analisis data, terdapat empat pola kalimat pada kelompok ini, yaitu (1) S-P-Pel; (2) S-P; (3) S-P-O; dan (4) S-P-O-Pel dengan rincian sebagaimana disajikan dalam tabel berikut.

\begin{tabular}{|c|c|c|c|}
\hline No. & Pola & $\begin{array}{c}\text { Jumlah } \\
\text { Data }\end{array}$ & Contoh Data \\
\hline 1. & S-P-Pel & 45 & $\begin{array}{l}\text { (1) } \mathbf{S} \text { [Yang ada di Jawa] P [semula berasal] Pel. [dari Cina Selatan.] } \\
\text { (2) } \mathbf{S} \text { [Collister] } \mathbf{P} \text { [jengkel] Pel. [pada dirinya sendiri.] } \\
\text { Berdasarkan analisis data, penulis menyimpulkan bahwa ada dua jenis pelengkap, } \\
\text { yaitu pelengkap yang fungsinya mendekati atau menyerupai fungsi keterangan } \\
\text { sehingga kehadirannya tidak wajib dalam sebuah konstruksi kalimat (seperti } \\
\text { kalimat 2) dan pelengkap yang fungsinya mendekati fungsi objek sehingga tidak } \\
\text { dapat dihilangkan (seperti kalimat 1). }\end{array}$ \\
\hline 2. & S-P & 18 & $\begin{array}{l}\text { (1) } \mathbf{S} \text { [Hasilnya] } \mathbf{P} \text { [lumayan.] } \\
\text { (2) } \mathbf{S} \text { [Usaha-usaha untuk mewujudkan kesejahteraan rakyat] } \mathbf{P} \text { [juga perlu ditingkatkan.] } \\
\text { Pola kalimat subjek-predikat merupakan pola kalimat dasar dalam bahasa } \\
\text { Indonesia.Pada data ditemukan pola kalimat S-P yang kedua unsurnya diperluas, } \\
\text { tetapi ada pula yang kedua unsurnya tidak diperluas. }\end{array}$ \\
\hline 3. & S-P-O & 37 & $\begin{array}{l}\text { (1) } \mathbf{S} \text { [Kepastian mengenai pengamatan mana yang benar,] } \mathbf{P} \text { [tentu masih memerlukan ] } \mathbf{O} \text { [data } \\
\text { statistik yang lebih lengkap dan akurat.] } \\
\text { (2) } \mathbf{S} \text { [Mobil seberat } 108 \mathrm{~kg} \text { yang dikemudikan Collister] } \mathbf{P} \text { [masih mulus merayapi] } \mathbf{O} \\
\text { [tanjakan.] }\end{array}$ \\
\hline 4. & S-P-O-Pel & 17 & $\begin{array}{l}\text { (1) } \mathbf{S} \text { [Calon pebisnis] } \mathbf{P} \text { [tentu perlu mencari] } \mathbf{O} \text { [informasi] Pel. [tentang supplier produk yang } \\
\text { cocok untuk konsep bisnis.] } \\
\text { (2) } \mathbf{S} \text { [Sekolah ini] } \mathbf{P} \text { [memilih] } \mathbf{O} \text { [pendidikan lingkungan hidup] Pel. [sebagai muatan lokal } \\
\text { pengajarannya.] } \\
\text { Berdasarkan analisis, pelengkap pada kalimat dengan pola S-P-O-Pel } \\
\text { kehadirannya tidak wajib. Hal ini disebabkan unsur objek yang telah hadir } \\
\text { mendahului unsur pelengkap dan memiliki fungsi yang lebih penting dibanding } \\
\text { unsur pelengkap. }\end{array}$ \\
\hline & JUMLAH & 117 & \\
\hline
\end{tabular}

\subsection{Perluasan Kalimat Tunggal}

\subsubsection{Perluasan Subjek}

Kalimat tunggal perluasan subjek yang ditemukan dalam data berjumlah 50 kalimat.Yang dikategorikan sebagai perluasan subjek adalah subjek yang terdiri atas dua frase atau lebih, misalnya frase nominal dan frase preposisional dan subjek yang memiliki perluasan berupa keterangan.Berikut contoh kalimat tunggal dengan perluasan subjek.
(1) $\mathbf{S}$ [Pemandangan di sebuah kereta api yang sebagian penumpangnya membaca, tidak saling tegur, ataupun senyum] P [merupakan] Pel. [indikasinya.]

(2) $\mathbf{S}$ [Penanganan untuk mengentaskan kaum miskin dari kemiskinan yang dilakukan sejak beberapa waktu,] $\mathbf{P}$ [sejauh ini masih dipertanyakan] Pel. [efektivitasnya.]

\subsubsection{Perluasan Subjek dan Pelengkap}

Kalimat dengan perluasan unsur subjek dan pelengkap seperti dalam contoh berikut ditemukan dalam data sebanyak 10 kalimat. 
Maria Christa I.K.: Struktur dan Keterbacaan Kalimat pada Buku Teks Pelajaran ...

$\mathbf{S}$ [Tawuran yang terjadi Sabtu menjelang tengah malam] $\mathbf{P}$ [dipicu] Pel. [oleh tewasnya Surya Hadi, warga Jalan Kesatriaan V RT 028/03, Kelurahan Kebon Manggis, Matraman, Jakarta Timur, yang lebih dikenal sebagai kawasan Berland.]

\subsubsection{Perluasan Subjek dan Predikat}

Kalimat yang mengalami perluasan subjek dan predikat berjumlah 6 kalimat. Meskipun sedikit, kalimat yang mengalami perluasan subjek dan pelengkap tetap menarik untuk dianalisis karena predikat yang berupa verba berderet masih jarang digunakan dalam sebuah kalimat.

(1) $\mathbf{S}$ [Helai daun gelombang cinta di sudut ruangan] $\mathbf{P}$ [berlekuk berirama.]

(2) $\mathbf{S}$ [Keris raksasa yang dipajang itu] $\mathbf{P}$ [berdiri tegak menambah] Pel. [keindahan pesta tanaman hias.]

\subsubsection{Perluasan Subjek dan Objek}

Dari data ditemukan 15 kalimat yang mengalami perluasan subjek dan objek. Berikut ini contoh kalimat yang mengalami perluasan subjek dan objek.

(1) S [Program-program yang dimaksudkan untuk membantu orang miskin itu] $\mathbf{P}$ [justru menimbulkan] $\mathbf{O}$ [dampak tidak sedap berupa penyelewengan.]

(2) $\mathbf{S}$ [Robert T. Kiyosaki dalam gagasannya 'how to get rich'] $\mathbf{P}$ [memberikan] $\mathbf{O}$ [enam kiat yang dapat diaplikasikan seseorang untuk menjadi kaya.]

\subsection{Struktur Kalimat Tunggal dengan Perluasan Keterangan}

Dari data yang dianalisis, ditemukan 123 kalimat tunggal dengan perluasan keterangan.Keterangan yang digunakan pun bermacam-macam, seperti yang terangkum dalam tabel di berikut ini.

\begin{tabular}{|c|c|c|c|}
\hline No. & $\begin{array}{c}\text { Jenis } \\
\text { Keterangan }\end{array}$ & $\begin{array}{c}\text { Jumlah } \\
\text { Data }\end{array}$ & Contoh Data \\
\hline 1. & Tempat & 22 & $\begin{array}{l}\text { S [Salah satu cara untuk mengakhiri sifat ini] } \mathbf{P} \text { [ialah] Pel. [memasyarakatkan semangat } \\
\text { kerja] ket.tempat [di kalangan masyarakat kita.] } \\
\text { Ada dua jenis keterangan tempat, yaitu keterangan tempat yang berfungsi } \\
\text { sebagai keterangan untuk seluruh unsur dalam kalimat dan keterangan } \\
\text { tempat yang berfungsi sebagai keterangan bagi salah satu unsur dalam } \\
\text { kalimat. }\end{array}$ \\
\hline 2. & Waktu & 21 & $\begin{array}{l}\text { S [Dua gelombang tawuran antarwarga di Jalan Matraman Raya] } \mathbf{P} \text { [terjadi] ket.waktu } \\
\text { [dalam } 16 \text { jam, Sabtu hingga Minggu (18/10) sore.] }\end{array}$ \\
\hline 3. & Tujuan & 15 & $\begin{array}{l}\text { ket. tujuan [Untuk memutus lingkaran kemiskinan itu,] P [dibutuhkan] S [program- } \\
\text { program semacam pendidikan, pelatihan-pelatihan keterampilan,serta dibantu } \\
\text { permodalan.] }\end{array}$ \\
\hline 4. & Cara & 10 & $\begin{array}{l}\mathbf{S} \text { [ICM yang didukung } 80 \text { asosiasi dari } 62 \text { negara di dunia] } \mathbf{P} \text { [berupaya ikut mengatasi] } \mathbf{O} \\
\text { [masalah wanita yang dihadapi oleh negara-negara berkembang] ket. cara [secara aktif.] }\end{array}$ \\
\hline 5. & Alasan & 9 & $\begin{array}{l}\text { ket. alasan [Melihat angka-angka tersebut,] S [kita] } \mathbf{P} \text { [berharap semestinya tidak terjadi] } \\
\text { Pel. [fenomena mengonsumsi nasi aking.] }\end{array}$ \\
\hline 6. & Kuantitas & 7 & $\begin{array}{l}\text { S [Harga sewanya] P [sama dengan] Pel. [EV 1,] ket. kuantitas [yaitu Rp } 126 \text { juta per tiga } \\
\text { tahun.] } \\
\text { Ada dua jenis keterangan kuantitas, yakni yang menuntut hadirnya unsur } \\
\text { predikat dan yang tidak menuntut kehadiran predikat seperti kalimat di atas. }\end{array}$ \\
\hline 7. & Modalitas & 5 & $\begin{array}{l}\text { ket. modalitas [Dapat dipastikan] S [Anthurium black beauty yang ada di pameran itu] P } \\
\text { [akan diburu] Pel. [oleh para penggemar tanaman hias.] } \\
\text { Keterangan modalitas yang digunakan dalam kalimat tersebut berfungsi } \\
\text { sebagai informasi tambahan unsur setelahnya, yaitu unsur subjek dan } \\
\text { predikat. Keterangan modalitas tersebut menerangkan subjek Anthurium } \\
\text { black beauty, predikat akan diburu, dan pelengkap oleh para penggemar. }\end{array}$ \\
\hline 8. & Perkecualian & 5 & $\begin{array}{l}\text { ket. perkecualian [Tidak hanya batu, kayu, dan Molotov,] } \mathbf{S} \text { [para pemuda itu] P [juga } \\
\text { melemparkan] } \mathbf{O} \text { [petasan.] } \\
\text { Keterangan perkecualian berfungsi untuk menerangkan hal perkecualian dari }\end{array}$ \\
\hline
\end{tabular}


Maria Christa I.K.: Struktur dan Keterbacaan Kalimat pada Buku Teks Pelajaran ...

\begin{tabular}{|c|c|c|c|}
\hline & & & $\begin{array}{l}\text { inti klausa dan sebagai keterangan penambahan seperti yang terdapat pada } \\
\text { kalimat di atas. }\end{array}$ \\
\hline 9 & Penerima & 4 & $\begin{array}{l}\text { S [Penghargaan Upakarti Jasa Kepeloporan] P [diberikan] ket.penerima [kepada } \\
\text { perusahaan, organisasi, lembaga, dan kelompok yang dengan prakarsa sendiri melakukan } \\
\text { program keterkaitan usahanya dengan industri kecil dan kerajinan.] } \\
\text { Pada kalimat tersebut, keterangan penerima wajib hadir dalam konstruksi } \\
\text { kalimat predikat yang digunakan mengharuskan hadirnya objek, keterangan, } \\
\text { atau unsur lainnya agar makna kalimat menjadi logis sehingga fungsi } \\
\text { keterangan penerima di atas menyerupai fungsi objek dalam sebuah struktur } \\
\text { kalimat. }\end{array}$ \\
\hline 10. & Asal & 4 & $\begin{array}{l}\text { ket. asal [Sesuai dengan namanya] S [Anthurium black beauty] P [memang tampak] Pel. } \\
\text { [sangat cantik.] } \\
\text { Keterangan asal berfungsi untuk menerangkan asal atau sumber suatu hal } \\
\text { dan bahan pembuatan. }\end{array}$ \\
\hline 11. & Perbandingan & 1 & $\begin{array}{l}\text { S [Jumlah pengguna mobil listrik di Amerika] P [tercatat lebih banyak] ket. } \\
\text { perbandingan [dibandingkan negara barat lainnya.] }\end{array}$ \\
\hline 12. & $\begin{array}{l}\text { Waktu \& } \\
\text { Tempat }\end{array}$ & 7 & $\begin{array}{l}\text { ket. waktu [Satu setengah tahun lalu] S [Tempo] P [menyaksikan] } \mathbf{O} \text { [sejumlah bangunan] } \\
\text { ket.tempat [di Suaka Margasatwa Muara Angke dan Pulau Rambut yang rusak.] }\end{array}$ \\
\hline 13. & Cara \& Tujuan & 3 & $\begin{array}{l}\text { S [Ali Umar] P [adalah] Pel. [pematung yang lebih jujur menyikapi realitas seni patung] } \\
\text { ket. cara [dengan cara "mengasong"] ket. tujuan [untuk menyambung hidup dan } \\
\text { membuat karya patung.] }\end{array}$ \\
\hline 14. & Alat \& Tempat & 2 & $\begin{array}{l}\text { S [Mereka] P [menawarkan] O [paket perjalanan] ket. tempat [ke Pulau Rambutan] ket. } \\
\text { alat [dengan kapal motor.] }\end{array}$ \\
\hline 15. & Cara \& Tempat & 2 & $\begin{array}{l}\text { ket. cara [Dalam sekejap,] S [patung kecil itu] P [pindah tangan] ket. tempat [ke } \\
\text { kolektor.] }\end{array}$ \\
\hline 16. & Waktu \& Cara & 2 & $\begin{array}{l}\text { ket. waktu[Suatu hari,] S [Collister] } \mathbf{P} \text { [tengah asyik mengendarai] } \mathbf{O} \text { [kendaraannya yang } \\
\text { melaju mulus] ket. cara [dengan nyaris tanpa bunyi itu.] }\end{array}$ \\
\hline 17. & $\begin{array}{l}\text { Tempat \& } \\
\text { Kuantitas }\end{array}$ & 2 & $\begin{array}{l}\text { S [Dia] P [tengah menuju] Pel. [rumahnya] ket. tempat [di Simi Valley, California,] ket. } \\
\text { kuantitas [kira-kira } 62 \mathrm{~km} \text { lagi.] }\end{array}$ \\
\hline 18. & $\begin{array}{l}\text { Kesertaan, } \\
\text { Tujuan, \& } \\
\text { Alasan }\end{array}$ & 2 & $\begin{array}{l}\mathbf{S} \text { [Saya] } \mathbf{P} \text { [bisa melakukan] } \mathbf{O} \text { [kolusi] ket. kesertaan [dengan pengusaha besar] ket. } \\
\text { tujuan [untuk menerima komisi dan bonus] ket. alasan [atas kemudahan dan "pelayanan" } \\
\text { yang diberikan.] }\end{array}$ \\
\hline 19. & $\begin{array}{l}\text { Asal, Kuantitas, } \\
\text { \& Tujuan }\end{array}$ & 1 & $\begin{array}{l}\text { S [Mobil listrik Collister prototype EV } 1 \text { itu] P [disewanya] ket. asal [dari General Motor] } \\
\text { ket. kuantitas [dengan tarif Rp126 juta] ket. tujuan [untuk masa sewa tiga tahun.] }\end{array}$ \\
\hline 20. & $\begin{array}{l}\text { Kesertaan, } \\
\text { Penerima, \& } \\
\text { Tempat }\end{array}$ & 1 & $\begin{array}{l}\text { ket. kesertaan [Bersama tiga rekan sekolahnya dari SMA Yayasan Memajukan Ilmu dan } \\
\text { Kebudayaan (YMIK) di Manggarai, Jakarta Selatan,] S [dia] P [menyerahkan] O [temuan } \\
\text { itu] ket. penerima [kepada tim juri yang menunggu] ket.tempat [di Suaka Margasatwa } \\
\text { Muara Angke.] }\end{array}$ \\
\hline & JUMLAH & 123 & \\
\hline
\end{tabular}

\subsection{Struktur Kaliamt Tunggal Inversi}

Kalimat inversi adalah kalimat yang predikatnya mendahului objek. Dalam struktur bahasa Indonesia, kalimat inversi yang berpola dasar predikat-subjek cukup banyak digunakan. Namun, seringkali penggunaan kalimat inversi tidak disadari karena terlihat seperti kalimat elips. Pada bagian ini, kalimat tunggal inversi dianalisis berdasarkan pola yang terbentuk, yaitu pola predikat-subjek dan pola keterangan predikat-subjek.

\subsubsection{Pola P-S}

Dari data, ditemukan 12 kalimat tunggal inversi dengan pola predikat-subjek. Berikut ini contoh kalimat tunggal inversi dengan pola P-S.

(1) $\mathbf{P}$ [Ada] $\mathbf{S}$ [dua hambatan terhadap cita-cita kesehatan setiap bangsa.] 
Maria Christa I.K.: Struktur dan Keterbacaan Kalimat pada Buku Teks Pelajaran ...

(2) $\mathbf{P}$ [Tidak ada] $\mathbf{S}$ [pohon bambu di Australia.]

(3) $\mathbf{P}$ [Sering muncul] $\mathbf{S}$ [kebingungan di benak mereka.]

\subsubsection{Pola K-P-S}

Dari data, terdapat 14 kalimat tunggal inversi dengan pola keterangan-subjek-predikat. Keterangan yang digunakan pada kalimat tunggal ini adalah keterangan waktu, keterangan tempat, dan keterangan tujuan.

(1) ket. tempat [Di sudut gerai] $\mathbf{P}$ [tampak] $\mathbf{S}$ [Anthurium gelombang cinta yang gagah.]

(2) ket. tujuan [Untuk mendapat gambaran yang lengkap dan utuh,] P [semestinya terkumpul dulu] S [semua indikator ekonomi yang relevan.]

\subsection{Struktur Kalimat Majemuk Setara}

Kalimat majemuk setara terdiri atas hubungan koordinasi yang menggabungkan dua klausa atau lebih yang masing-masing mempunyai kedudukan setara dalam struktur konstituen kalimat (TBBI, 2003:386). Hubungan koordinasi yang terjalin di dalam kalimat majemuk setara dapat dilihat dari penggunaan konjungsi di dalamnya. Berdasarkan hubungan koordinasi yang terjalin di dalamnya, kalimat majemuk setara dapat dibedakan menjadi kalimat majemuk setara dengan hubungan pemilihan, kalimat majemuk setara hubungan penambahan, dan kalimat kalimat majemuk setara hubungan pertentangan. Dalam data, hanya ditemukan kalimat majemuk setara hubungan penambahan dan kalimat majemuk setara hubungan pertentangan.

\subsubsection{Hubungan Penambahan}

Salah satu ciri kalimat majemuk setara hubungan penambahan adalah penggunaan beberapa konjungsi seperti dan dan serta. Dari data yang ditemukan terdapat 17 kalimat majemuk setara hubungan penambahan.

(1) ket. waktu [Setengah jam kemudian,] S [para pengantar jenazah itu] P [kembali] konj. [dan] P [melintas] ket. tempat [di sisi bagian Tegalan]

(2) $\mathbf{S}$ [Semuanya] $\mathbf{P}$ [memiliki] $\mathbf{O}$ [harga jual yang tinggi] konj. [dan] $\mathbf{P}$ [sangat diminati] $\mathbf{O}$ [para penggemar tanaman hias.]

\subsubsection{Hubungan Pertentangan}

Kalimat majemuk setara hubungan pertentangan ditandai dengan adanya penggunaan konjungsi seperti tetapi dan sedangkan. Berikut ini contoh kalimat majemuk setara hubungan pertentangan yang ditemukan dalam data.

(1) $\mathbf{S}$ [Pematung] $\mathbf{P}$ [tidak lagi bekerja] konj. [dan] $\mathbf{P}$ [berpikir] ket. tujuan [untuk karya yang independen,] konj. [tetapi] $\mathbf{P}$ [menunggu] $\mathbf{O}$ [pasokan ide] ket. asal [dari pasar patung monumen] ket. tujuan [untuk kepentingan kekuasaan.]

(2) $\mathbf{P}$ [Tidak ada] $\mathbf{S}$ [korban jiwa dalam tawuran itu,] konj. [tetapi] S [pagar pembatas Jalan Matraman Raya yang diharapkan mampu meredam tawuran] P [dijebol] ket. tempat [di dua tempat.]

\subsection{Struktur Kalimat Majemuk Bertingkat}

Kalimat majemuk bertingkat adalah kalimat yang terjalin dari hubungan subordinasi, yaitu penggabungan dua klausa atau lebih sehingga terbukti kalimat majemuk yang salah satu klausanya menjadi bagian dari klausa yang lain. Oleh karena itu, hubungan yang terjalin dalam kalimat majemuk bertingkat tidak memiliki kedudukan yang setara. Konjungsi yang digunakan dapat menjadi salah satu ciri kalimat majemuk bertingkat. Konjungsi tersebut antara lain bahwa, sebelum, jika, ketika, kalau, karena, sehingga, dan lain sebagainya.

\subsubsection{Hubungan Waktu}

Klausa yang terjalin dalam kalimat majemuk bertingkat hubungan waktu menyatakan waktu terjadinya peristiwa atau keadaan yang dinyatakan dalam klausa utama. Dengan demikian, klausa bawahan yang terdapat dalam kalimat majemuk bertingkat merupakan bagian atau anak kalimat yang menyatakan hubungan waktu dengan klausa utama. Dari data, terdapat 16 kalimat majemuk bertingkat hubungan waktu. Berikut ini beberapa contoh kalimat tersebut.

(1) $\mathbf{S}$ [Thorne] $\mathbf{P}$ [mendapat] $\mathbf{O}$ [ilham] konj. [setelah] $\mathbf{P}$ [melihat] $\mathbf{O}$ [perahu rakit bambu yang ada di British Museum.]

(2) S [Matanya] P [terbelalak] konj. [ketika] $\mathbf{S}$ [dia] $\mathbf{P}$ [melihat] $\mathbf{O}$ [cairan kimia berwarna kuning yang digunakan untuk mengawetkan kerang.]

\subsubsection{Hubungan Syarat}

Hubungan subordinasi syarat terjalin dalam kalimat majemuk bertingkat yang klausa bawahannya menyatakan syarat terlaksananya apa yang disebut dalam klausa utama. Konjungsi yang digunakan untuk 
menjalin hubungan syarat tersebut antara lain adalah jika dan kalau. Dari data, terdapat 10 kalimat majemuk bertingkat hubungan syarat. Berikut ini beberapa contohnya.

(1) $\mathbf{S}$ [Saya] $\mathbf{P}$ [akan menjadi] Pel. [pecundang] konj. [jika] $\mathbf{P}$ [menuruti] $\mathbf{O}$ [semua dorongan dan godaan itu.]

(2) $\mathbf{S}$ [Manusia Wajak (Wajak adalah desa di dekat Madiun, Jawa Timur)] P [mempunyai] Pel. [ciri-ciri tubuh yang lebih progresif] konj. [kalau] P [dibandingkan] Pel. [dengan manusia kera sebelumnya, Pithecanthropus Erectus.]

\subsubsection{Hubungan Komplementasi}

Dalam hubungan komplementasi pada kalimat majemuk bertingkat, klausa subordinatif melengkapi apa yang dinyatakan oleh predikat pada klausa utama. Konjungsi yang digunakan dalam kalimat majemuk bertingkat hubungan komplementasi adalah bahwa. Dari data yang ditemukan, terdapat 12 kalimat majemuk bertingkat hubungan komplementasi seperti dua contoh kalimat di bawah ini.

(1) $\mathbf{S}$ [Kita] $\mathbf{P}$ [juga tahu] konj. [bahwa] $\mathbf{S}$ [kesehatan seseorang] P [diawali] ket. waktu [sejak pembuahan terjadi dan kehamilan berlangsung

(2) S [Ini semua] P [akan menjadi] Pel. [bahan perenungan kita semua,] konj. [bahwa] S [hidup sehat itu] $\mathbf{P}$ [dapat dilakukan] $\mathbf{O}$ [setiap orang.]

\subsubsection{Hubungan Penyebaban}

Dari data, terdapat 15 kalimat majemuk bertingkat hubungan penyebaban. Hubungan penyebaban terdapat dalam kalimat yang klausa subordinatifnya menyatakan sebab atau alasan terjadinya hal yang dinyatakan dalam klausa utama. Berikut ini adalah beberapa contoh kalimat majemuk bertingkat hubungan penyebaban.

(1) $\mathbf{S}$ [Pesimisme Ali Umar] $\mathbf{P}$ [tidak berlebihan] ket. sebab

[karena dalam pameran ini hanya satu karya terjual.]

(2) $\mathbf{S}$ [Kondisi tersebut] $\mathbf{P}$ [bisa terjadi] konj. [karena] $\mathbf{S}$ [seseorang] $\mathbf{P}$ [tidak bisa menerima] $\mathbf{O}$ [challenge.]

(3) $\mathbf{S}$ [Gangguan mogok] $\mathbf{P}$ [mengancam] ket. waktu [setiap saat] konj. [sebab] $\mathbf{S}$ [daya jelajah mobil listrik] $\mathbf{P}$ [cuma] Pel. [112 km atau $114 \mathrm{~km}$.]

\subsection{Stuktur Kalimat Majemuk Bersusun}

Kalimat majemuk bersusun dapat berupa kombinasi atau gabungan kalimat majemuk bertingkat, gabungan kalimat majemuk setara, dan kalimat majemuk bertingkat dengan kalimat majemuk setara atau sebaliknya. Dari data, ditemukan 13 kalimat majemuk bersusun.

\subsubsection{Gabungan Kalimat Majemuk Bertingkat dan Majemuk Setara}

Seperti yang telah disebutkan, kalimat majemuk bersusun dapat berupa gabungan kalimat majemuk bertingkat dan kalimat majemuk setara. Hubungan yang terjalin pada kalimat majemuk bertingkat dan kalimat majemuk setara tersebut berbeda-beda. Berikut ini contoh kalimat majemuk bersusun yang merupakan gabungan kalimat majemuk bertingkat dan kalimat majemuk setara.

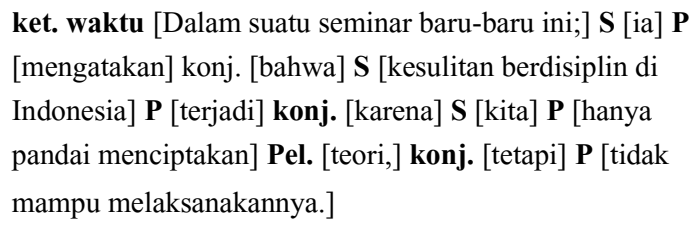

Yang menarik adalah pada tersebut terjadi tiga hubungan sekaligus dalam satu kalimat majemuk bersusun. Kalimat ini terdiri atas kalimat majemuk bertingkat hubungan komplementasi, kalimat majemuk bertingkat hubungan penyebaban dan kalimat majemuk setara hubungan pertentangan. Kalimat majemuk bertingkat hubungan komplementasi pada kalimat majemuk bersusun di atas dijalin dengan konjungsi bahwa dan karena, sedangkan kalimat majemuk setara hubungan pertentangannya dijalin dengan konjungsi tetapi. Kalimat majemuk setara yang dijalin dengan konjungsi tetapi menerangkan hubungan pertentangan dari kalimat majemuk bertingkat hubungan penyebaban dengan konjungsi karena. Selanjutnya, kalimat majemuk bertingkat hubungan penyebaban tersebut menerangkan hubungan komplementasi yang hadir sebelumnya.

\subsubsection{Gabungan Kalimat Majemuk Bertingkat}

Kalimat bersusun yang terdiri atas gabungan kalimat majemuk bertingkat dapat terjalin dari hubungan yang berbeda-beda. Berikut ini contoh kalimat majemuk bersusun yang terdiri atas gabungan kalimat majemuk bertingkat.

S [Menteri Kesehatan dan Kesejahteraan Sosial, Ahmad Sujudi,] P [menegaskan] konj. [bahwa] S [pemerintah] $\mathbf{P}$ [berupaya melengkapi] $\mathbf{O}$ [fasilitas puskesmas dan rumah sakit] ket. tujuan [untuk menangani ibu hamil dan 
Maria Christa I.K.: Struktur dan Keterbacaan Kalimat pada Buku Teks Pelajaran ...

melahirkan] konj. [sehingga] S [angka kematian ibu (AKI)

di Indonesia, yang paling tinggi untuk kawasan Asia

Pasifik,] P [dapat ditekan] Pel. [sekecil mungkin.]

Dari konjungsi yang digunakan terlihat bahwa kalimat tersebut merupakan gabungan kalimat majemuk bertingkat hubungan komplementasi dan kalimat majemuk bertingkat hubungan hasil. Konjungsi tersebut adalah bahwa dan sehingga. Sama seperti yang telah dijelaskan sebelumnya, hubungan hasil yang terdapat pada kalimat ini merupakan bagian yang berfungsi menerangkan hubungan komplementasi yang hadir sebelumnya.

\subsubsection{Gabungan Kalimat Majemuk Setara}

Salah satu hubungan yang terjalin pada kalimat majemuk bersusun yang terdiri atas gabungan kalimat majemuk setara adalah kalimat majemuk setara dengan hubungan pertentangan dan kalimat majemuk setara hubungan penambahan. Hubungan tersebut dapat terlihat dari contoh di bawah ini.

ket. alasan [Dengan munculnya nama-nama terakhir itu,] $\mathbf{S}$ [mereka] P [tidak cuma nekat menabrak] $\mathbf{O}$ [konvensi seni patung,] konj. [tetapi] $\mathbf{P}$ [juga menambahkan] $\mathbf{O}$ [porsi elemen ruang yang lebih dari karya patung konvensional,] $\mathbf{P}$ [cenderung bersifat instalatif,] konj. [dan] $\mathbf{P}$ [memasukkan] $\mathbf{O}$ [materi yang tidak biasa.]

Dari kalimat tersebut, terlihat bahwa hubungan setara pertentangan dan penambahan terjalin dengan konjungsi tetapi dan dan. Hubungan pertentangan yang hadir terlebih dahulu dalam konstruksi kalimat memiliki bagian lain yang menjelaskan hubungan tersebut, yaitu hubungan penambahan yang hadir setelahnya. Dalam data, kalimat bersusun yang terdiri atas gabungan kalimat majemuk setara tidak terlalu banyak ditemukan. Hal ini disebabkan oleh hubungan dalam kalimat majemuk setara tidak begitu banyak. Dengan demikian, dapat disimpulkan bahwa dalam kalimat majemuk bersusun yang terdiri atas gabungan kalimat majemuk setara.

\subsection{Struktur Kalimat Tak Lengkap}

Kalimat taklengkap pada dasarnya adalah kalimat yang tidak ada subjek dan/atau predikatnya. Hal ini biasa terjadi di dalam wacana karena unsur yang tidak muncul itu sudah diketahui atau disebutkan sebelumnya. (TBBI, 2000:363). Pada bagian ini analisis terhadap kalimat taklengkap dilakukan berdasarkan jenis-jenis kalimat taklengkap yang ditemukan dalam data, yaitu kalimat sampingan, kalimat elips, dan kalimat minor. Dari data yang ditemukan terdapat 103 kalimat taklengkap.

\subsubsection{Kalimat Sampingan}

Kalimat sampingan adalah kalimat taklengkap yang terbentuk dari klausa taklengkap dan diturunkan dari kalimat bersusun. Dengan kata lain, kalimat sampingan merupakan bagian dari kalimat majemuk bertingkat atau setara yang berdiri sendiri. Secara sintaksis, unsur yang terdapat di dalamnya biasanya sudah lengkap, tetapi secara keseluruhan tidak bermakna (tidak ada inti). Berikut ini beberapa contoh kalimat sampingan yang ditemukan dalam data.

(1) konj. [Sehingga] $\mathbf{S}$ [perawatan pasien] $\mathbf{P}$ [disesuaikan] ket. cara [dengan standar perawatan tumor jinak.]

(2) konj. [Tetapi] S [kami] P [juga bisa melanjutkan] $\mathbf{O}$ [perkara] ket. tempat [dari sudut pidana.]

Kedua kalimat di atas merupakan contoh kalimat sampingan yang berasal dari kalimat majemuk. Kalimat pertama merupakan klausa terikat yang berasal dari kalimat majemuk bertingkat pengganti keterangan akibat, sedangkan kalimat kedua merupakan klausa terikat dari kalimat majemuk setara pengganti keterangan pertentangan. Hal ini terjadi karena pembuat kalimat menganggap bahwa kalimat ini (yang sebenarnya hanya sebuah klausa terikat) sudah memiliki inti kalimat atau pokok pikiran, padahal kalimat tersebut hanyalah merupakan keterangan tambahan dari kalimat sebelumnya yang seharusnya dirangkai menjadi satu kalimat majemuk. Berikut ini adalah salah satu penggalan bacaan yang menunjukkan keterikatan kalimat sampingan dengan kalimat sebelumnya.

Berdasarkan hasil uji sampel setelah operasi, tumor di dalam tubuh Sita tidak ganas. Sehingga perawatan pasien disesuaikan dengan standar perawatan tumor jinak. Setelah menjalani perawatan beberapa hari kesembuhan yang didamba tak kunjung datang.

Hasil penelitian kedua ini tidak diberitahukan kepada pasien. Sebab selama hampir setahun Sita terus diperiksa ke RSPI tentang perkembangan operasinya. Barulah pada Februari 2006 (tiga bulan sebelum meninggal), Sita menerima hasil sampel kedua, saat ia kembali kontrol ke RSPI. 
Maria Christa I.K.: Struktur dan Keterbacaan Kalimat pada Buku Teks Pelajaran ...

Dalam penggalan bacaan di atas terlihat bahwa kalimat sampingan Sehingga perawatan pasien disesuaikan dengan standar perawatan tumor jinak dan Sebab selama hampir setahun Sita terus diperiksa ke RSPI tentang perkembanga operasinya memiliki keterikatan makna dengan kalimat sebelumnya. Oleh karena itu, untuk memperbaiki jenis kalimat seperti ini agar menjadi kalimat yang efektif, diperlukan langkah penggabungan dengan kalimat sebelumnya agar klausa terikat yang sebenarnya tidak dapat berdiri sendiri tersebut menjadi bagian dari sebuah kalimat mejemuk.

\subsubsection{Kalimat Elips}

Kalimat elips adalah kalimat taklengkap yang terjadi karena pelesapan beberapa bagian dari klausa dan diturunkan dari kalimat tunggal. Kalimat ini merupakan kalimat yang tidak lengkap unsurunsurnya secara sintaksis. Berikut ini beberapa contoh kalimat elips yang ditemukan dalam data.

(1) P [Adalah] Pel. [zat pengawet mayat.]

(2) $\mathbf{P}$ [Disediakan] $\mathbf{O}$ [sarana transportasi dan tempat tinggal (asrama)] ket. waktu [mengikuti pendidikan baik di Jakarta maupun di luar negeri.]

Kedua kalimat di atas terlihat tidak memiliki subjek. Pada kalimat (1) predikat yang digunakan adalah adalah, sedangkan pada kalimat (2) predikat yang digunakan adalah disediakan. Kalimat elips yang ditemukan dalam data tidak terlalu banyak. Hal ini disebabkan kalimat elips lebih sering digunakan dalam kalimat yang menjelaskan sesuatu dengan kalimat yang banyak dan berjejeran sehingga subjeknya sama terus. Untuk menghilangkan kebosanan karena subjeknya sama, dihilangkanlah subjek tersebut. Oleh karena itu, muncul kalimat yang kehilangan subjeknya.

\subsubsection{Kalimat Minor}

Kalimat minor adalah kalimat yang tidak berstruktur klausa dan pola intonasi final. Beberapa kalimat yang termasuk dalam jenis kalimat minor adalah panggilan, salam, ucapan, seruan, judul, moto, inskripsi, dan ungkapan khusus. Pada bagian ini, penulis hanya memfokuskan analisis pada kalimat minor jenis inskripsi, yaitu kalimat yang hanya berupa beberapa unsur kalimat yang tidak berstruktur lengkap. Berikut ini beberapa contoh kalimat minor yang ditemukan dalam data.

(1) $\mathbf{S}$ [Dua sekutu yang masih banyak dihadapi para ibu kita, yang sesungguhnya dapat dicegah dengan cara sederhana.]

(2) ket. waktu [Rekonstruksi 40.000 tahun lalu.]

(3) konj. [Tetapi] konj. [karena] S [berevolusi dalam satu jangka waktu yang panjang dan tersebar di beberapa tempat, genus homo yang tadinya satu ini sukar dibayangkan akan menghasilkan keturuan yang transfertil.

Dari ketiga kalimat di atas, terlihat bahwa terdapat beberapa jenis kalimat minor, yaitu kalimat yang hanya terdiri atas satu unsur kalimat seperti pada kalimat (1) dan kalimat (2) serta kalimat yang menggunakan konjungsi tetapi tidak memiliki makna seperti pada kalimat (3). Dalam data, kalimat minor yang hanya terdiri atas satu unsur kalimat cukup banyak ditemukan. Sebagai contoh, kalimat tersebut hanya terdiri atas unsur subjek atau unsur keterangan saja. Hal ini dapat saja terjadi karena kalimat tersebut merupakan bagian dari kalimat sebelumnya yang ditulis terpisah. Kemungkinan lain adalah pembuat kalimat merasa sudah membubuhkan predikat pada kalimat minor yang terdiri atas unsur subjek saja, tetapi predikat tersebut hanya berupa keterangan. Oleh karena itu, kalimat yang hadir merupakan kalimat taklengkap strukturnya dan tidak memiliki inti kalimat.

\subsection{Keterbacaan Kalimat}

Salah satu cara untuk mengukur keterbacaan sebuah kalimat adalah dengan melihat jumlah kata dalam kalimat tersebut. Seperti yang telah dijelaskan sebelumnya, menurut Felicia Utorodewo dalam makalahnya yang berjudul "Tinjauan Buku Teks Pelajaran Bahasa Indonesia", pedoman untuk mengukur keterbacaan dalam sebuah kalimat dengan menghitung jumlah katanya.

Setelah dilakukan penghitungan jumlah kata pada setiap kalimat yang ditemukan dalam data, hasil yang didapat adalah sebagai berikut (1) sebanyak 24,15\% atau 106 kalimat masuk ke dalam kategori sangat mudah dipahami; (2) sebanyak $17,77 \%$ atau 78 kalimat masuk ke dalam kategori mudah dipahami; (3) sebanyak 15,72\% atau 69 kalimat masuk ke dalam kategori agak mudah dipahami; (4) sebanyak 16,17\% 
Maria Christa I.K.: Struktur dan Keterbacaan Kalimat pada Buku Teks Pelajaran ...

atau 71 kalimat masuk ke dalam kategori standar; (5) sebanyak 13,21\% atau 58 kalimat masuk ke dalam kategori agak sulit dipahami; (6) sebanyak 7, $29 \%$ atau 32 kalimat masuk ke dalam kategori sulit dipahami; dan (7) sebanyak 5, 69\% atau 25 kalimat masuk ke dalam kategori sangat sulit dipahami.

Namun dari hasil penghitungan tersebut, penulis hanya menganalisis contoh kalimat dari data yang jumlah katanya 25-29 kata. Hal ini didasari adanya pandangan bahwa jumlah kata 25-29 dalam sebuah kalimat termasuk dalam kategori sulit dipahami dan sangat sulit dipahami. Menurut penulis, kedua kategori tersebut merupakan kategori yang paling penting dianalisis karena sudah termasuk sulit dan sangat sulit dipahami.

\subsubsection{Keterbacaan Kalimat yang Terdiri Atas 25-28 Kata}

Dalam data, ditemukan 32 kalimat terdiri atas 25-28 kata. Berikut ini beberapa contoh kalimat yang termasuk dalam kategori ini.

(1) S-perluasan [Seorang pemimpin yang hanya memerintahkan apa yang harus kita kerjakan tanpa diimbangi dengan pemberian nafkah yang kita butuhkan] $\mathbf{P}$ [menyulitkan] $\mathbf{O}$ [kita] ket. tujuan [untuk menegakkan disiplin yang diperlukan.]

(2) Artinya, konj. [walaupun] $\mathbf{S}$ [seseorang] $\mathbf{P}$ [menyadari] konj. [bahwa] $\mathbf{S}$ [apa yang dikerjakan] $\mathbf{P}$ [perlu] konj. [dan] $\mathbf{P}$ [telah memperoleh] $\mathbf{O}$ [imbalan yang pantas] konj. [karena] $\mathbf{P}$ [terbiasa hidup santai] konj. [atau] $\mathbf{P}$ [malas,] S [disiplin yang diperlukan itu] $\mathbf{P}$ [sulit terwujud.]

Kalimat (1) terdiri atas 26 kata dan termasuk dalam kategori kalimat yang sulit dipahami. Dari strukturnya, kalimat tersebut diklasifikasikan sebagai kalimat tunggal dengan perluasan keterangan tujuan. Dengan pengklasifikasian tersebut, dapat dikatakan bahwa struktur sintaksis kalimat (1) berterima. Namun, penyebab kalimat (1) tersebut masuk ke dalam kategori sulit dipahami adalah perluasan subjek yang terlalu panjang. Menurut penulis, perluasan subjek pada kalimat (1) dapat dijadikan kalimat terpisah yang diletakkan sebelum kalimat tersebut. Kalimat terpisah ini dapat berupa kalimat lengkap yang berisi informasi tambahan atau keterangan subjek yang akan hadir pada kalimat setelahnya, yaitu kalimat (1) tersebut. Dengan demikian, subjek pada kalimat (1) dapat dibuat lebih ringkas sehingga kalimat dapat lebih mudah dipahami.

Selain hal di atas, penggunaan interogativa apa pada perluasan subjek membuat kalimat terkesan lebih sulit dipahami. Interogativa merupakan kategori dalam kalimat interogatif yang berfungsi menggantikan sesuatu yang ingin diketahui oleh pembicara. Lebih lanjut, interogativa-dalam TBBI interogativa disebut pronomina penanya-disebut juga sebagai pemarkah pertanyaan. Dari kedua hal tersebut, penulis menyimpulkan bahwa interogativa hanya dapat digunakan dalam kalimat interogatif. Dengan demikian, penggunaan interogativa apa pada kalimat (1) di atas merupakan sesuatu yang kurang tepat dan mungkin saja membuat kalimat tersebut menjadi lebih sulit dipahami.

Selanjutnya, kalimat (2) terdiri atas 28 kata dan termasuk kalimat dengan kategori sulit dipahami. Berbeda dengan kalimat (1), kalimat (2) diklasifikasikan sebagai kalimat taklengkap, yaitu gabungan dua kalimat sampingan. Oleh karena itu, kemungkinan penyebab kalimat (2) sulit dipahami adalah strukturnya yang tidak memang lengkap. Kalimat (2) juga dapat dikatakan sebagai kalimat yang tidak efektif karena penggunaan konjungsi yang berlebihan. Konjungsi yang digunakan dalam kalimat (2) adalah walaupun, bahwa, dan, karena, dan atau. Penggunaan kelima konjungsi yang kurang tepat ini dapat pula menyebabkan kalimat menjadi tidak memiliki inti. Menurut penulis, kelima konjungsi tersebut digunakan dalam satu kalimat karena ingin menyajikan banyak informasi dan keterangan secara bersamaan. Perbaikan yang dapat dilakukan terhadap kalimat tersebut adalah dengan membuatnya menjadi kalimat terpisah. Kalimat terpisah tersebut dapat berupa kalimat majemuk setara atau kalimat majemuk bertingkat sehingga kalimat (2) tidak lagi menjadi kalimat yang sulit dipahami dan tidak efektif.

\subsubsection{Keterbacaan Kalimat yang Terdiri Atas 29 Kata atau Lebih}

Kategori sangat sulit dipahami (29 kata atau lebih) merupakan kategori tertinggi dalam pengukuran keterbacaan berdasarkan jumlah kata. Dalam data ditemukan 25 kalimat yang terdiri atas 29 kata atau lebih. Berikut ini beberapa contoh kalimat tersebut. 
Maria Christa I.K.: Struktur dan Keterbacaan Kalimat pada Buku Teks Pelajaran ...

(1) konj. [Sementara itu,] $\mathbf{S}$ [tawuran Minggu sore] $\mathbf{P}$ [dipicu] O-perluasan [ulah para pengantar jenazah Surya Hadi yang mengobrak-abrik dagangan bakso milik Erick yang mangkal di trotoar Jalan Matraman Raya, persis di sisi kiri Toko Buku Gramedia.]

(2) konj. [Dan] P [adalah] Pel. [suatu hal yang tragis, ] konj. [bahwa] $\mathbf{S}$ [masyarakat di negara-negara berkembang yang tengah sibuk melawan penyakitpenyakit yang muncul akibat ekologi kemiskinan di satu pihak,] ket. waktu [pada waktu yang sama] S [mereka] P [juga terancam] Pel.-perluasan [oleh penyakit-penyakit yang muncul dari gaya hidup orang modern di pihak lain.]

(3) ket. perwatasan [Untuk ukuran Asia,] S [Jepang] P [menempati] $\mathbf{O}$ [peringkat pertama dalam penggunaan mobil listrik] konj. [karena] ket. tempat [di negara itu] $\mathbf{S}$ [masalah lingkungan hidup] $\mathbf{P}$ [telah dipahami benar] Pel. [oleh masyarakat,] ket. asal [misalnya saja dikenalnya gerakan pemulungan limbah industri untuk didaur ulang.]

Kalimat (1) terdiri atas 33 kata dan termasuk dalam kalimat dengan kategori sangat sulit dipahami. Kalimat (1) dapat diklasifikasikan sebagai kalimat tunggal dengan perluasan keterangan objek. Konjungsi antarkalimat sementara itu memang menunjukkan adanya hubungan waktu dari kalimat sebelumnya. Namun, penulis mengganggap bahwa kalimat (1) dikategorikan sebagai kalimat tunggal. Hal ini disebabkan kalimat (1) hanya terdiri atas satu klausa atau hanya memiliki satu inti kalimat. Selanjutnya, kalimat (1) terlihat memiliki tiga konstituen pada perluasan keterangan objeknya. Ketiga konstituen tersebut adalah keterangan pekerjaan yang dilakukan objek para pengantar jenazah Surya yaitu mengobrak-abrik dagangan baso milik Erik, keterangan pekerjaan atau hal yang dilakukan oleh barang dagangan Erik tersebut, yaitu mangkal dan keterangan tempat atau letak dagangan baso milik Erik, yaitu di trotoar Jalan Matraman Raya, persis di sisi kiri Toko Buku Gramedia. Hadirnya ketiga konstituen tersebut pada perluasan keterangan objek kalimat (1) menjadi salah satu penyebab kalimat tersebut menjadi sulit dipahami.

Namun, menurut penulis kalimat (1) masih dapat dipahami karena perluasan keterangan objek tersebut cukup jelas dan melekat pada objek yang hadir sebelumnya. Hal ini berbeda dengan kalimat (2) yang diklasifikasikan sebagai kalimat taklengkap, yaitu kalimat sampingan. Kalimat (2) yang strukturnya tidak berterima tersebut membuat kalimat tidak memiliki inti. Hal itu pula yang dapat membuat kalimat sulit dipahami. Dalam kalimat (2), penggunaan konjungsi dan di awal kalimat menunjukkan kalimat tersebut merupakan bagian dari kalimat sebelumnya. Selain itu, penggunaan predikat adalah dan konjungsi bahwa pada kalimat (2 terlihat tidak efisien karena tidak memiliki fungsi.

Selanjutnya, kalimat (3) yang terdiri atas 33 kata di atas dapat diklasifikasikan sebagai kalimat majemuk bertingkat hubungan penyebaban. Dengan melihat jumlah kata yang terdapat di dalamnya, kalimat (3) dikategorikan ke dalam kalimat yang sangat sulit dipahami. Banyaknya jumlah kata pada kalimat (3) menyebabkan kalimat menjadi sulit dipahami. Penyebab lain adalah kalimat tersebut diperluas pula dengan beberapa keterangan seperti keterangan perwatasan, keterangan asal, dan keterangan tempat. Menurut penulis, kalimat majemuk bertingkat sebaiknya hadir dengan sebanyak-banyaknya satu klausa utama dan satu klausa bawahan sehingga tidak menimbulkan kesulitan untuk memahaminya. Perbaikan kalimat (3) dapat dilakukan dengan memisahkan kalimat majemuk bertingkat dan membuat kalimat tunggal yang memuat informasi lainnya.

\section{PENUTUP}

Struktur kalimat pada buku teks pelajaran bahasa Indonesia terbitan tahun 1988, tahun 2001, dan tahun 2008 menunjukkan bahwa unsur pelengkap mempunyai dua fungsi, yaitu fungsinya yang menyerupai objek sehingga kehadirannya menjadi wajib dalam konstruksi kalimat dan fungsinya yang menyerupai keterangan dan membuat kehadirannya tidak wajib dalam struktur kalimat. Selanjutnya, untuk fungsi keterangan dalam penelitian ini ditemukan bahwa keterangan memiliki dua fungsi, yaitu untuk menerangkan seluruh unsur dalam konstruksi kalimat dan untuk menerangkan hanya salah satu unsur dalam konstruksi kalimat. Fungsi yang menerangkan seluruh unsur dalam konstruksi kalimat memang dapat dihilangkan, tetapi akan mengurangi informasi penting dalam kalimat tersebut. Sebaliknya, keterangan yang berfungsi hanya menerangkan salah satu unsur dalam konstruksinya dapat dihilangkan tanpa mengubah makna kalimat tersebut. 
Maria Christa I.K.: Struktur dan Keterbacaan Kalimat pada Buku Teks Pelajaran ...

Penelitian ini juga menunjukkan bahwa perluasan unsur predikat yang jarang sekali digunakan dalam sebuah konstruksi kalimat dapat dilakukan dengan menggunakan verba berderet seperti berlekuk berirama dan berdiri tegak. Hal ini juga menjadi salah satu penyebab perluasan unsur predikat jarang digunakan, yaitu sulitnya menemukan padanan verba berderet. Selanjutnya, dalam struktur kalimat inversi, unsur predikat yang digunakan dapat menentukan perpindahan posisi dengan unsur subjek mendahului unsur tersebut. Yang ditemukan adalah predikat dalam kalimat inversi yang berupa ada dan negasinya (tidak ada) tidak dapat diletakkan setelah unsur subjek, tetapi predikat yang berupa verba atau nomina seperti sering muncul atau akan semakin optimal dapat diletakkan setelah unsur subjek.

Selain itu, penelitian ini menunjukkan bahwa kalimat majemuk setara baik hubungan penambahan maupun hubungan pertentangan memiliki dua jenis, yaitu kalimat majemuk setara dengan subjek yang sama dan predikat yang berbeda serta kalimat majemuk setara dengan subjek yang sama dan objek yang berbeda pada klausa-klausa yang terjalin di dalamnya.

Selanjutnya, penelitian ini menunjukkan bahwa dalam kalimat majemuk bertingkat beberapa hubungan seperti hubungan waktu dan hubungan hasil, subjek, dan hubungan syarat yang subjek pada klausa utama diulang atau dilesapkan pada klausa bawahan. Namun, pada kalimat majemuk bertingkat hubungan komplementasi dan hubungan penyebaban tidak terjadi repetisi atau pelesapan subjek. Hal ini disebabkan oleh klausa bawahan pada kalimat tersebut merupakan bagian lain yang terikat dan menjelaskan hal yang berbeda dari klausa utamanya.

Analisis terhadap kalimat majemuk bersusun yang merupakan gabungan dari beberapa kalimat majemuk dalam penelitian ini menunjukkan bahwa hubunganhubungan yang terjalin di dalamnya merupakan hubungan dengan makna yang saling terkait dan tidak dapat dipisahkan. Selain itu, hubungan yang hadir lebih awal dari hubungan yang lain dalam kalimat majemuk bersusun merupakan bagian yang diterangkan oleh hubungan tersebut.

Temuan yang tidak kalah penting dalam penelitian ini adalah banyaknya kalimat taklengkap yang digunakan pada buku teks pelajaran bahasa Indonesia.
Jumlah kalimat taklengkap ini menempati posisi kedua dalam jenis kalimat yang ditemukan dalam ketiga buku teks pelajaran bahasa Indonesia. Kalimat taklengkap yang ditemukan adalah kalimat sampingan, kalimat elips, dan kalimat minor. Dari ketiga jenis kalimat taklengkap tersebut, kalimat minor merupakan kalimat terbanyak yang ditemukan. Salah satu kalimat yang termasuk kalimat minor adalah kalimat yang tidak memiliki struktur yang jelas, misalnya kalimat yang hanya berupa keterangan dan kalimat tanpa subjek atau kalimat tanpa predikat. Dengan demikian, penulis berasumsi bahwa ketiga buku teks pelajaran bahasa Indonesia yang di dalamnya masih terdapat banyak penggunaan kalimat taklengkap belum memiliki tingkat keterbacaan yang cukup bagi siswa kelas III SMA.

Selain melakukan pengamatan pada struktur kalimat pada ketiga buku teks pelajaran bahasa Indonesia yang diasumsikan berpengaruh pada tingkat keterbacaannya, penulis juga melakukan pengamatan dengan salah satu cara mengukur tingkat keterbacaan sebuah kalimat, yaitu dengan menghitung jumlah kata yang digunakan dalam sebuah kalimat. Dari penghitungan sederhana tersebut, ditemukan bahwa jumlah kalimat paling banyak adalah kalimat dengan kategori sangat mudah dipahami, yaitu sebanyak 106 kalimat (24,15\%). Meskipun demikian, masih terdapat sekitar 12,98\% kalimat yang masuk kategori sulit dipahami dan sangat sulit dipahami. Jumlah ini memang termasuk sedikit, tetapi perlu mendapat perhatian. Oleh karena itu, penyajian buku teks pelajaran bahasa Indonesia selanjutnya diharapkan lebih memerhatikan jumlah kata yang digunakan dalam kalimat.

Dari penelitian ini, beberapa cara dapat dilakukan untuk pengadaan buku teks pelajaran bahasa Indonesia-khususnya buku teks pelajaran bahasa Indonesia kelas 3 SMA-yang lebih baik seperti menggunakan kalimat yang berstruktur lengkap dan memiliki maksimal dua inti atau klausa di dalamnya. Hal ini dilakukan agar kalimat tersebut lebih mudah dipahami. Selain itu, kalimat yang digunakan dalam buku teks pelajaran bahasa Indonesia tersebut setidaknya terdiri atas $11-17$ kata karena jumlah tersebut masuk dalam kategori kalimat standar dan mudah dipahami. 
Maria Christa I.K.: Struktur dan Keterbacaan Kalimat pada Buku Teks Pelajaran ...

Selanjutnya, hasil penelitian ini dapat diberikan kepada beberapa pihak yang terkait dengan pengadaan buku teks pelajaran bahasa Indonesia seperti penulis buku teks pelajaran bahasa Indonesia, penerbit pemerintah dan penerbit swasta, serta Pusat Kurikulum dan Perbukuan Departemen Pendidikan dan Kebudayaan. Pemberian hasil penelitian kepada penulis buku teks pelajaran bahasa Indonesia dilakukan agar penulis membuat kalimat-kalimat dalam buku pelajaran tersebut dengan kriteria yang telah disebutkan di atas. Untuk penerbit swasta dan penerbit pemerintah serta Pusat Kurikulum dan Perbukuan Departemen Pendidikan dan Kebudayaan, pemberian hasil penelitian ini dilakukan agar pihakpihak tersebut dapat melakukan verifikasi bukubuku teks pelajaran bahasa Indonesia dengan melihat kalimat-kalimat yang ada di dalamnya.

\section{DAFTAR PUSTAKA}

Alwi, Hasan, dkk. 1998. Tata Bahasa Baku Bahasa Indonesia, Edisi Ketiga. Jakarta: Balai Pustaka.

Badan Bahasa. 2011. Undang-Undang Republik Indonesia Nomor 24 Tahun 2009 tentang Bendera, Bahasa, dan Lambang Negara, serta Lagu Kebangsaan. Jakarta: Badan Pengembangan dan Pembinaan Bahasa.

Departemen Pendidikan Nasional. 2005. Standar Penilaian Buku Pelajaran Bahasa dan Sastra Indonesia. Jakarta: Pusat Perbukuan dan Kurikulum Depdiknas.

Direktorat Pembinaan SMA. 2010. "Rekapitulasi Jumlah Siswa SMA dan SMK," dalam http://bit.ly/In8MSW, diakses 30 April 2012.

Gilliland, John. 1972. Readability. London: Holder and Stroughton.

Harjasujana, A.S dan Yeti Mulyati. (1997). Membaca 2. Jakarta: Departemen Pendidikan dan Kebudayaan.

Kridalaksana, Harimurti, dkk. 1999. Tata Bahasa Deskriptif Bahasa Indonesia: Sintaksis (Naskah Kelima). Jakarta: Fakultas Sastra, Universitas Indonesia.

Kridalaksana, Harimurti. 2001. Kamus Linguistik, Edisi Ketiga. Jakarta: Gramedia Pustaka Utama.

Kusmana, Suherli. 2008. “Keterbacaan Buku Teks Pelajaran,” dalam http://bit.ly/IOR2w8, diakses 30 April 2012.

Nurlaili. 2011. "Pengukuran Tingkat Keterbacaan Wacana dalam LKS Mata Pelajaran Bahasa Indonesia Kelas 4-6 SD dan Keterpahamiannya," dalam http://bit.ly/IhMaio, diakses 30 April 2012.

Parera, Jos Daniel. 1988. Sintaksis. Jakarta: PT. Gramedia Pustaka Utama.

Pusat Kurikulum dan Perbukuan Departemen Pendidikan Nasional. "Penilaian Buku Teks Pelajaran,” dalam http://bit.ly/IDxecA, diakses 30 April 2012.

Ramlan, M. 2001. Sintaksis. Yogyakarta: CV Karyono.

Rumadi, A. dan V. Sudiati. 1988. Buku Pelajaran Bahasa dan Sastra Indonesia. Jakarta: Gramedia Pustaka Utama.

Sadikin, Asep Ganda, dkk. 2001. Mari Mengangkat Martabat Bahasa Kita: Bahasa Indonesia Buku Pelajaran untuk SMU Kelas III Berdasarkan Suplemen GBPP 1999, Pembelajaran Mengarah pada Kurikulum Kompetensi Dasar. Bandung: PT. Grafindo Media Pratama.

Santoso, Gunawan Budi, dkk. 2008. Terampil Berbahasa Indonesia 3 Program IPA dan IPS untuk Kelas XII SMA/MA. Jakarta: Pusat Perbukuan Departemen Pendidikan Nasional.

Sihombing, Liberty P. dan Djoko Kentjono. 2005 "Sintaksis," dalam Pesona Bahasa: Langkah Awal Memahami Linguistik. Eds. Kushartanti, Untung Yuwono, dan Multamia RMT Lauder. Jakarta: PT Gramedia Pustaka Utama. 
Maria Christa I.K.: Struktur dan Keterbacaan Kalimat pada Buku Teks Pelajaran ...

Suladi, dkk. 2000. Keterbacaan Kalimat Bahasa Indonesia dalam Buku Pelajaran Bahasa Indonesia. Jakarta:

Pusat Bahasa Departemen Pendidikan dan Kebudayaan.

Utorodewo, Felicia Nuradi. 2007. “Tinjauan Buku Teks Pelajaran Bahasa Indonesia,” dalam http://bit.ly/JnGq7G, diakses 30 Oktober 2011.

Yurnaldi. "Pelajaran Bahasa Indonesia Makin Tidak Diminati," dalam Kompas, 31 Oktober 2008.

\section{CATATAN BELAKANG}

1) Data Puspendik menyebutkan nilai rata-rata ujian nasional mata pelajaran bahasa Indonesia untuk kelas 3 SMA adalah sebagai berikut, untuk jurusan IPA tahun 2006 nilai rata-ratanya 7,90, tahun 2007 nilai rata-ratanya 7,56, dan tahun 2008 nilai rata-ratanya 7,60, sedangkan untuk jurusan IPS tahun 2006 nilai rata-ratanya 7,26, tahun 2007 nilai rata-ratanya 6,95, dan tahun 2008 nilai rata-ratanya 6,95 .

2) Berdasarkan data Kemdikbud, dari 50 soal UN tahun 2008 dan 2009, 19 soal berupa soal yang berhubungan dengan teks dan pada UN tahun 2010 terdapat 17 soal yang berhubungan teks. Rincian jumlah bacaan pada UN tahun 2008, 2009 , dan 2010 adalah sebagai berikut. Pada UN tahun 2008 ditemukan 11 bacaan umum dan 5 bacaan sastra, pada UN tahun 2009 ditemukan 15 bacaan umum dan 4 bacaan sastra, dan pada tahun 2010 ditemukan 17 bacaan umum dan 4 bacaan sastra. 